To link to this article / Para enlazar con este artículo:

https://doi.org/10.14198/fem.2020.35.02

To cite this article / Para citar este artículo:

Ozonas Marcos, Margarita. «How to integrate a gender perspective into well-being budgeting practices: Insights from a comparative case study between Bhutan and New Zealand». En Feminismo/s, 35 (junio 2020): 29-61. Monographic dossier / Dossier monográfico: A critical practice of thinking otherwise: Bacchi, Gender and Public Policy Analysis, coord. Angela O'Hagan, DOI: 10.14198/fem.2020.35.02

\title{
HOW TO INTEGRATE A GENDER PERSPECTIVE INTO WELL-BEING BUDGETING PRACTICES: INSIGHTS FROM A COMPARATIVE CASE STUDY BETWEEN BHUTAN AND NEW ZEALAND
}

\section{CÓMO INTEGRAR LA PERSPECTIVA DE GÉNERO EN LOS PRESUPUESTOS DE BIENESTAR: IDEAS DE UN ESTUDIO COMPARATIVO ENTRE BUTÁN Y NUEVA ZELANDA}

\author{
Margarita OzONAS MARCOS \\ Independent freelance \\ http://www.consultant-gender-equality.com/ \\ marga.ozonas@gmail.com \\ orcid.org/0000-0001-8942-2709
}

\begin{abstract}
Well-being gender budgeting (WBGB) experiences use a multidimensional approach for planning and budgeting combining the Capability Approach along with gender responsive budgeting, which entails a feminist approach. However, what happens to the other well-being budgeting initiatives that do not explicitly include this «gender focus» in their conceptualization?

Based on the central question expressed by Carol Bacchi - «What is the problem represented to be?»-, this article explores the gender bias that can be found in well-being budgeting that does not fit into the category of WBGB and the difficulties of integrating a gender perspective in these practices. It is based on the review of the documentation of the main well-being domains, political priorities and tools used from 2019-2020 in Bhutan and New Zealand. The article concludes with some insights and recommendations to merge GRB practices into well-being budgeting approaches.
\end{abstract}


How to integrate a gender perspective into well-being budgeting practices:

Insights from a comparative case study between Bhutan and New Zealand

Keywords: Well-being Budgeting; Well-being Gender Budgeting; Gender Responsive Budgeting; Capability Approach; Gender Mainstreaming.

\section{Resumen}

Las experiencias de presupuestos de bienestar y género (PBG) utilizan un enfoque multidimensional en el que combinan dos enfoques, uno basado en las capacidades y otro basado en presupuestos con enfoque de género. Sin embargo, ¿qué sucede con las otras iniciativas presupuestarias de bienestar que no incluyen explícitamente este «enfoque de género» en su conceptualización?

En base a la pregunta central expuesta por Carol Bacchi: «iCuál es el problema representado en cuestión?», este artículo explora los sesgos de género que pueden encontrarse en presupuestos de bienestar que no se ajustan a la categoría explícita de los PBG y las dificultades que puede entrañar integrar la perspectiva de género en estas prácticas. Se basa en la revisión bibliográfica de los principales dominios de bienestar, prioridades políticas y herramientas utilizadas en Bután y Nueva Zelanda en 2019 y 2020. El artículo concluye con algunas ideas y recomendaciones para fusionar las prácticas de presupuestos con enfoque de género con los presupuestos de bienestar.

Palabras clave: presupuestos de bienestar; presupuestos de bienestar y género; presupuestos con enfoque de género; enfoque de capacidades: transversalización del enfoque de género.

\section{INTRODUCTION}

\subsection{Background}

The 2030 Sustainable Development Goals (SDGs) pledge to «leave no one behind» recognizes that «extreme inequality persists within countries and cities as well as among countries» (United Nations, Leaving no one behind 3 ). Despite progress made in many countries around the world, gender inequality is still a global problem (United Nations, Leaving no one behind 34) and in addition, we are experiencing a tremendous climate crisis. How can policymakers address all of these issues? Just as problems are interrelated, so are the solutions to poverty, inequality, climate change and other global challenges (United Nations, The Sustainable Development Goals 3). These multiple and interconnected crises, including that of gender inequality, undermine 
How to integrate a gender perspective into well-being budgeting practices:

Insights from a comparative case study between Bhutan and New Zealand

attainment of collective well-being (Trebeck $1^{1}$ ). Policymakers have to find a solution through innovative, multidimensional and strategic planning and budgeting. Well-being budgeting (WBB) presents a potentially promising solution. Furthermore, introducing Gender Responsive Budgeting (GRB) into well-being budgeting practices supports the SDGs of «leaving no one behind», promoting gender equality and empowering specific segments of the population. GRB is embedded in international agreements and commitments such as CEDAW and SDG indicator 5C1 «Proportion of countries with systems to track and make public allocations for gender equality and women's empowerment». (UN Women, Financing for Gender Equality 18 February 2020)

This article presents a comparative study of two cases of well-being budgeting from Bhutan and New Zealand: two countries of different sizes and contexts that decided to adopt a wellbeing approach to public policy at national government level, but with almost a 50-year gap in implementation, different conceptual well-being frameworks and different policy tools. A critical point of reflection in this article is to identify to what extent WBB approaches in Bhutan and New Zealand conceptualize well-being from a gender perspective, examining how the problem of gender inequality is represented in their respective well-being approaches, and if the policy tools used integrate a gender perspective.

This article aims to provide some insights that can enrich present and future WBB experiences by adapting some existing GRB approaches to gender-neutral WBB practices ${ }^{2}$, and considering the possible difficulties this might imply. To do this, the article engages with Carol Bacchi's «What is the problem represented to be?» (WPR) approach (2009) as an analytical framework through which to critically explore this inquiry, probing implicit gender biases in the problem representation of well-being and proposing possible solutions to how WBB can be conceptually conceived in a gender-neutral or gender-blind way.

1. This paper was commissioned by the Women's Budget Group to inform the Commission on a Gender-Equal Economy. At the time of writing this article, this paper was not yet been published.

2. In this article, references to "gender-sensitive» means that the gender perspective is taken into account. «Gender blind» and «gender-neutral» are terms used interchangeably and means that this perspective is not taken into account.

Feminismo/s 35, junio 2020, pp. 29-61 
There are two related policy and budgetary practices that consider the gender perspective in exploring WBB in the comparative case study and which are used in the WPR analysis: 1) Gender responsive budgeting (GRB) for which the literature dates back to the 1990s with gender mainstreaming in policymaking as the underlying approach, and 2) well-being gender budgeting (WBGB), which appeared in the literature in the 2000s and reconciles the well-being approach with the GRB approach.

\subsection{Structure}

Section one sets out the principal method used and the findings from a literature review and a documentary analysis of information collected from public governmental websites of Bhutan and New Zealand, comprising the main well-being domains, policy priorities and tools used in 2019-2020. These inform a set of comparative tables and illustrative figures elaborated by the author. The first section of this paper introduces the concepts of GRB, the Capability Approach as an inspiring framework for WBB and WBGB and describes the interrelations of these three concepts. The second section presents Carol Bacchi's analytical framework «What is the problem represented to be?» (2009) applied to WBB. The third section compares the well-being budgeting practices of Bhutan and New Zealand focusing on the conceptualization of well-being and the main tools used to assess whether well-being is considered from a gender perspective in the policy and budget cycle. The fourth section discusses conceptual frameworks and tools in relation to stated well-being aspirations and Bacchi's recommendations for improving gendered policymaking. The last section concludes with insights and recommendations on integrating the gender perspective in well-being budgets.

\section{GENDER RESPONSIVE BUDGETING, WELL-BEING BUDGET AND WELL-BEING GENDER BUDGETING: CONVERGENCES AND DIVERGENCES}

\subsection{Gender responsive Budgeting (GRB)}

GRB emerged as a key strategy to integrate a gender perspective into fiscal policies following feminist economic thinking in the 1980s. The main goal of GRB is to promote gender equality and redress inequality (Budlender and 
How to integrate a gender perspective into well-being budgeting practices:

Insights from a comparative case study between Bhutan and New Zealand

Hewitt 7; Council of Europe 10; Stotsky 4; Downes, Von Trapp, and Nicol 6) through gender responsive planning and budget allocations by governments. It is a concept aligned with gender mainstreaming, defined by The Council of Europe as follows:

The (re)organization, improvement, development and evaluation of policy processes, so that a gender equality perspective is incorporated in all policies at all levels and at all stages, by the actors normally involved in policymaking. (Council of Europe 8).

GRB aims to allocate resources to meet the different needs and priorities of men and women -needs and priorities that differ in nature- to allow men and women to achieve equality of outcomes from economic policies (Galizzi, Bassani, and Cattaneo 3). For GRB to be truly transformative, «it must be embedded in its feminist roots» (Khan 7): that means transforming gender blind budgets by adding a gender lens. GRB implementation can take different forms, depending on several factors that determine the scope, methods used and actors involved as Table 1 shows.

Table 1. Possibilities in GRB implementation

\begin{tabular}{|c|c|}
\hline Approaches & $\begin{array}{l}\text { - Gender responsive budgeting, } \\
\text { - Well-being gender budgeting, } \\
\text { - Socially inclusive and gender responsive budgeting, } \\
\text { - Integrating gender perspectives into participatory budgeting, } \\
\text { - Child friendly and gender responsive budgeting }\end{array}$ \\
\hline $\begin{array}{l}\text { Stages of the } \\
\text { budget cycle }\end{array}$ & $\begin{array}{l}\text { - Budget preparation, } \\
\text { - Budget approval, } \\
\text { - Budget execution, } \\
\text { - Budget audit and evaluation } \\
\end{array}$ \\
\hline $\begin{array}{l}\text { Scope of the } \\
\text { budget }\end{array}$ & $\begin{array}{l}\text { - Public spending } \\
\text { - Public revenues }\end{array}$ \\
\hline $\begin{array}{l}\text { Level of } \\
\text { government }\end{array}$ & $\begin{array}{l}\text { - National level } \\
\text { - Sub-national level (e.g. regional/autonomous; municipal level) }\end{array}$ \\
\hline $\begin{array}{l}\text { Governmental } \\
\text { planning }\end{array}$ & $\begin{array}{l}\text { - Policy priorities } \\
\text { - Specific sectors, programmes or projects }\end{array}$ \\
\hline
\end{tabular}

Feminismo/s 35, junio 2020, pp. 29-61 
How to integrate a gender perspective into well-being budgeting practices:

Insights from a comparative case study between Bhutan and New Zealand

\begin{tabular}{|c|c|}
\hline $\begin{array}{l}\text { Actors } \\
\text { involved and } \\
\text { coordinating } \\
\text { bodies }\end{array}$ & $\begin{array}{l}\text { - Actors inside the government } \\
\text { - Actors outside the government } \\
\text { - Coordinating mechanisms (e.g. GRB committee, gender focal } \\
\text { points in institutions, etc.) }\end{array}$ \\
\hline $\begin{array}{l}\text { Basic requisites } \\
\text { and other } \\
\text { conditions }\end{array}$ & $\begin{array}{l}\text { - Ability or capacity to conduct a gender analysis at all stages of } \\
\text { budget development and throughout the budget process } \\
\text { - Access to sex-disaggregated data and gender statistics } \\
\text { - Capacity building } \\
\text { - Other favourable conditions }\end{array}$ \\
\hline Methods & $\begin{array}{l}\text { - Integrating gender perspectives into performance-based and } \\
\text { programme-based budgeting } \\
\text { - Categorizing budget programmes and gender analysis } \\
\text { requirements } \\
\text { - Tracking financial allocations to promote women's rights and } \\
\text { gender equality } \\
\text { - Costing approaches }\end{array}$ \\
\hline Tools & - Ex ante, concurrent and ex-post tools \\
\hline
\end{tabular}

Source: Author's own elaboration

GRB implies the integration of a gender perspective into all stages of the budget cycle including multiannual and annual budget processes (Anwar, Downes, and Davidson 6; Downes, Von Trapp, and Nicol 6; Stotsky 14; Villagómez et al. 14; Khan 3). This requires gender analyses at all stages of budget development (Klatzer and Stiegler 2; Khan 3) and throughout the budget process to assess whether its composition responds to the pursued gender equality objectives.

Knowing how to conduct a gender analysis is a basic pre-requisite for GRB implementation, as it requires an understanding of how gender inequalities arise, the underlying structural causes, and how to tackle the ways in which they are manifested through gender responsive policies and budgets. In addition, GRB requires conducting assessments at different stages of the policy-budget cycle, especially to assess the impact of government revenue and expenditure on women and men, girls and boys (Budlender and Hewitt 7; Council of Europe 10). However, government institutions do not always have the capacity to integrate gender into budgetary policies (Budlender, Sharp, and Allen 8) and there is often a lack of knowledge about gender mainstreaming in theory and in practice (Villalba, Jubeto, and Guridi 6). For 
this reason, capacity building on gender analysis and gender mainstreaming is another requisite in GRB implementation. Strengthening the capacity of budget actors, through skills and knowledge transfer is critical (Khan 4). Access to sex-disaggregated data and gender statistics are also another basic pre-requisite for gender assessments and to mainstream a gender approach into the budget cycle. Another indispensable step is to collect quantitative and qualitative data and produce gender-related indicators on a regular basis. Likewise, collecting other categories of data, such as age, ethnicity, urban/ rural areas, etc., will provide data for «socially inclusive budgeting», a process by which the rights of all, in particular those suffering from poverty and exclusion, are better reflected in public policymaking, notably in the government budget (United Nations, Leaving no one behind 6). In many countries GRB initiatives have improved the availability of sex-disaggregated data essential for assessing budgetary impacts and for improving statistics and indicators when they have successfully engaged with performance budgeting systems (Sharp and Elson 2). In addition to these pre-requisites, there are other favourable conditions that can contribute to establishing GRB including a series of contextual, normative, institutional, and relational conditions (O'Hagan 237).

There is a wide range of methodologies and tools for GRB implementation, as Table 1 shows, and which vary according to the context and objectives (Anwar, Downs, and Davidson 6). Ronnie Downes, Lisa von Trapp and Scherie Nicol (7) in their study «Gender Budgeting in OECD Countries» classify gender budgeting interventions into three relevant stages in the budget process: ex-ante, concurrent, and ex-post.

\subsection{The Capability Approach: Inspiring framework for Well-being Budgeting (WBB)}

Amartya Sen, Martha Nussbaum and Ingrid Robeyns have been among the major contributors to the Capability Approach. This alternative framework for social justice is based on the notion of capabilities, that is, individuals' functioning and freedom of choice. Capabilities are potential functioning, for example, people's access to sufficient food, taking part in the community, having shelter, relating to other people, working in the labour market, caring for others, and being healthy (Robeyns, «Sens Capability» 63). These 
How to integrate a gender perspective into well-being budgeting practices:

Insights from a comparative case study between Bhutan and New Zealand

functionings can also incorporate subjective values such as «being happy» (Sen, Inequality 39).

The conceptual framework of the Capability Approach, has inspired WBB practices and used, «to measure well-being recognizing its complexity and the interaction of different dimensions of well-being» (Addabbo et al. «Senegal» 15). A wellbeing economy pursues the social foundations of gender equality, social equity, peace and justice, health, food, water and education that must be secured within environmental boundaries (Coscieme et al. 5). In 2018, Scotland, Iceland and New Zealand established the Wellbeing Economy Governments (Wellbeing Economy Website, 27 February 2020). The wellbeing economy proposes that

Economics and business practices need to be reoriented to what an economy should actually deliver: an equitable distribution of wealth, health and wellbeing, while protecting the planet's resources for future generations and other species» (Hough-Steward et al. 6).

Previous well-being practices have been developed in various countries and have been quite diverse to date. The oldest one comes from the nation of Bhutan and is «the most widely known example of wellbeing policy», where well-being is linked to the concept of «happiness» with the «rationale for making happiness an integral part of its public policy» (Biswas-Diener, Diener, and Lyubchik 2). In 1972, Bhutan's fourth king Jigme Singye Wangchuck declared: «Gross National Happiness is more important than Gross National Product» (Government of Bhutan GNH Centre Website, 27 February 2020). By July 2008, Bhutan had officially enshrined Gross National Happiness (GNH) in its constitution. Bhutan was the first country to focus its planning and budgeting system to respond to the GNH Index.

In sum, there have been a variety of WBB practices, as the concept of well-being is open to multiple interpretations, and the methods and tools used will differ based on those interpretations. Trebeck categorizes well-being as «a multifaceted concept» and highlights that, besides all different meanings and interpretations, it is possible to broadly cluster them in two main categories: definitions that emphasize self-reported well-being, and collective and multidimensional well-being (3). As the findings in this article show, how these categories are applied in WBB policymaking has implications for the achievement of gender equality outcomes.

Feminismo/s 35, junio 2020, pp. 29-61 
How to integrate a gender perspective into well-being budgeting practices:

Insights from a comparative case study between Bhutan and New Zealand

If the variables and indicators included in a WBB approach are limited, the advancement of gender equality is reduced, as evidenced here in the examples from Bhutan and New Zealand which spotlight the weaknesses of the WBB approaches followed there. The first consideration refers to the subjective dimension of well-being. For Nussbaum and Sen, the Capability Approach includes subjective concepts of well-being, such as «pleasures, happiness, or desire fulfilment» regarded as parameters of «personal utility» (Sen, «Capability and Well-being» 2). Citing Sen (The idea of justice), Alkire clarifies that «happiness is often recognized as a dimension of well-being in the Capability Approach» (8), and according to Stewart, the subjective measures of happiness in the Capability Approach form the focus of the Happiness Approach today (3). The well-being conceptualization in Bhutan focuses on happiness, which fits the subjective dimension in the Capability Approach.

As a policy framework, the Happiness Approach has a series of limitations. The first is the difficulty of setting objectives, as there is no consensus of what is meant by «happiness» (Stewart 5). Secondly, «the approach must nevertheless be practical in the sense of being usable for actual assessments of the living standard» which «imposes restrictions on the kinds of information that can be required and the techniques of evaluation that may be used» (Sen, «Standard» 20). Then, there are difficulties in the use of subjective measures for policy purposes (Binder 8; Alkire 10) due to measurement imprecision and bias (Binder 4). For example, in self-reporting well-being processes, some individuals may report high levels of happiness in a context of structural inequalities (Trebeck 4). Middlemiss, citing Ahmed, highlights gender bias in self-reported well-being in a context of socially accepted discriminatory gender roles whereby:

Happiness has been used to promote a range of unsavory agendas in the past, including the subjugation of women ( Women are happy being in caring roles»)... [Ahmed] points out that if happiness becomes an aim, it also becomes a duty, and then to be unhappy is to be «causing trouble». In the context of feminism, this means the unhappy woman, the feminist, is a «killjoy,» when another framing might cast her as the freedom fighter (Middlemiss 1).

Another limitation of the Capability Approach in the pursuit of gender equality outcomes is when it takes the form of «collective well-being». There is 
How to integrate a gender perspective into well-being budgeting practices:

Insights from a comparative case study between Bhutan and New Zealand

no judgement about distribution beyond some distributional implications giving priority to universal access or to some critical capabilities (Stewart 8). Second, there is a risk of simplifying and clustering all the needs and interests of women and men, girls and boys (different population groups) as a unified and homogeneous group.

Historically, feminists have shown that when policy focuses on the collective level, instead of the individual, the needs and experiences of women can be subsumed by those of the collective; their voices silenced or talked over when the collective is represented; and that analysis at the collective, or household level can mask poverty, financial control and other forms of violence and abuse (Trebeck 4).

Both cases, New Zealand and Bhutan, follow an approach of collective and multidimensional well-being with the further complication of the case of Bhutan being built on the Happiness Approach.

\subsection{Well-being Gender Budgeting (WBGB)}

Before examining the concept of well-being gender budgeting it is important to understand the academic contributions, especially those of Robeyns and Nussbaum, to incorporate gender equality in the Capacity Approach. Robeyns highlighted weaknesses in how the Capability Approach responds to gender inequality

One of the crucial questions that Sen has not answered is which capabilities are relevant for assessing inequality. In other words, Sen has not proposed a well-defined list of capabilities (Robeyns, «Capability» 62).

Robeyns and Nussbaum subsequently proposed a list of capabilities that are relevant for gender equality, contributing to this analytical gap (See: Nussbaum, «Human» 83-5; Nussbaum, Women 78-86; Robeyns, «Capability» 74). For Robeyns, gender inequality includes gender division and time use of paid and unpaid work (household work and care work) (Robeyns, «Justice» 14). Nussbaum (Women) has emphasized the importance of reproductive health and reproductive rights, the negative effects of domestic violence, women's education and socio-economic status, participation in the labour market and time autonomy (Addis et al. 8). 
Aligned with these contributions, there have been feminist examinations of the broad concept of well-being, which entails knowledge of the different roles played by men and women in the definition of well-being (Addabbo, «Gender budgeting» WISE 3) and requires micro and macro analysis (Addabbo et al, «Social-reproduction» 106). Well-being is defined at the individual level and this, according to feminist economics, requires investigating what happens inside the family and recognizing the possibility of conflicts among its members regarding the construction of well-being (Addabbo, «Gender budgeting» WISE 3). This means an assessment of distribution of resources, work (both paid and unpaid), responsibilities and power relationships between institutions and residents (Addabbo et al., "Social-reproduction» 106).

Well-being gender budgeting practices have emerged as an approach to revealing and addressing gendered inequalities in terms of well-being (Klatzer et al. 116), inspired by a revised Capability Approach with a gender approach as well as by the feminist examination of the broad concept of well-being. (Gunluk-Senesen et al. «Gender budgeting in Turkey» 179). To date there is limited literature on this approach. According to Addabbo et al., "the Capability Approach to gender budgeting is a relatively underexplored area of research» («Senegal»1), confirmed by Klatzer et al. (134), who consider a group of Italian academics, notably Addabbo and Picchio, to have led the application of the theoretical framework of WBGB.

WBGB literature makes reference to how the Capability Approach has been used in auditing gender budgeting practices in public service provision (Addabbo, Lanzi, and Picchio, «Gender auditing» 1; Yucel and GunlukŞenesen 2) and auditing the gender impact of policies on well-being (Addabbo, «Gender budgeting» WISE 3). This approach has been applied mostly at local level in municipalities and universities in Italy, Turkey and Spain (Klatzer et al. 123) and Senegal. In the example of municipal budgeting in Turkey, WBGB was introduced as part of a GRB initiative supported by United Nations. In this case, a list of capabilities relevant for gender equality were used along with a set of indicators, presented in a matrix (Gunluk-Senesen et al., "Gender budgeting in Turkey» 184). 


\subsection{Well-being Gender Budgeting (WBGB): Between Gender Responsive Budgeting (GRB) and Well-being Budgeting (WBB)}

In this section, the relationship among of three described budgetary practices is explored. As figure 1 shows, WBGB is the point of convergence in the conceptualization of WBB and GRB.

The concept of GRB differs from WBB as GRB does not necessarily encompass the multidimensional notion of well-being and Capability Approach, except when conceptualized as WBGB (Addabbo et al., «Social-reproduction» 105). Alternatively, «WBGB goes beyond GRB, since it includes the auditing of institutional budgets from the well-being perspective» (Addabbo, RodríguezModroño, and Gálvez-Muñoz 1).

On the other hand, both GRB and WBGB share a feminist way of thinking in their conceptualization while WBB does not include this in its conceptualization. Figure 1 below illustrates the overlap where both WBGB and GRB approaches take into account feminist demands in the original concept of GRB, such as the visibility and recognition of women's unpaid work and social reproduction including care and household work, informal work and time use.

Figure 1. Similarities and differences among the conceptualization of WBB, WBGB and GRB
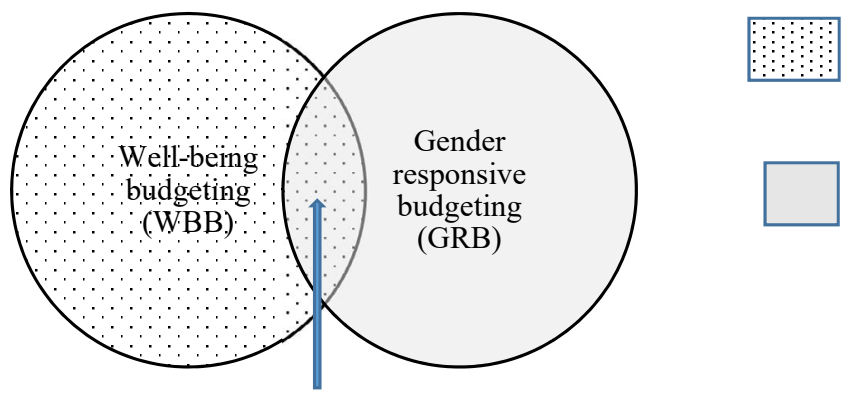

Well-being conceptualization: Capability approach

Feminist conceptualization: Care economy, social reproduction work, addressing roots of gender discrimination

Well-being gender budgeting (WBGB)

Source: Author's own elaboration

Feminismo/s 35, junio 2020, pp. 29-61 
How to integrate a gender perspective into well-being budgeting practices:

Insights from a comparative case study between Bhutan and New Zealand

A distinction between WBGB and GRB, is that WBGB is used as a framework to carry out gender analysis and guide public policy and budgeting, converting public resources into individual and social well-being, thereby supporting the expansion of capabilities and the effective functioning of both women and men (Addabbo et al., «Senegal» 1). Based on a list of essential capabilities and functions, the WBGB approach combines the individual's functions with policy domains and areas of responsibility of the government for service provision (Klatzer et al. 122).

As with GRB, WBGB implies assessing the impact that policies have on women and men's well-being, in all its multiple dimensions, as demonstrated in the previous example of well-being gender analysis in Turkey (Yucel and Gunluk-Senesen 272). It is necessary to assess the potential gender differentiated impacts that policies may have on individuals and inside households that can give rise to an unequal development of capabilities (Addabbo, «Gender budgeting» WISE 4). Picchio (1) described that as women are the main caregivers of children and the elderly, in a context where child care and elder care public services are rationed (e.g. Italy), this can have negative effects on the development of their other capabilities who as principal carers face time constraints and discrimination in their access to the labour market.

\section{CAROL BACCHI'S CONCEPTUAL FRAMEWORK: WHAT IS THE PROBLEM REPRESENTED TO BE? APPLIED TO WELL-BEING BUDGETING}

Bacchi's «What is the problem represented to be?» (WPR) approach is an analytical framework intended to facilitate critical interrogation of public policies. It starts from the premise that what one proposes to do about something reveals what one thinks is problematic (needs to change). Following this thinking, policies and policy proposals contain implicit representations of what is considered to be the «problem» («problem representations») (Bacchi, «Introducing» 21). The task in a 'WPR' analysis is to read policies with an eye to discerning how the 'problem' is represented and to subject this problem representation to critical scrutiny. That means, to put «problems» into question in order to identify where the implicit bias in the problem conceptualization is and what could be a solution to avoid this implicit bias. This

Feminismo/s 35, junio 2020, pp. 29-61 
How to integrate a gender perspective into well-being budgeting practices:

Insights from a comparative case study between Bhutan and New Zealand

article focuses on the implicit bias inherent in the problem representation that well-being is gender-neutral, that means, in general terms well-being is conceptualized in a gender blind way.

Bacchi proposed a set of six questions to analyse problem representation in order to scrutinize policy proposals, their potential impact, and for thinking how else the problem representation could be addressed. Table 2 below applies these questions to well-being budgeting.

Table 2. Using WPR for WBB

\begin{tabular}{|c|c|}
\hline Questions & Answers \\
\hline $\begin{array}{l}\text { 1. What's the «problem» represented } \\
\text { to be in a specific policy or policy } \\
\text { proposal? }\end{array}$ & $\begin{array}{l}\text { Gender analysis is not reflected in well- } \\
\text { being conceptualization, and the main } \\
\text { policy tools used are designed without a } \\
\text { gender approach. Gender mainstreaming } \\
\text { is lacking. }\end{array}$ \\
\hline $\begin{array}{l}\text { 2. What presuppositions or assumptions } \\
\text { underpin this representation of the } \\
\text { «problem»? }\end{array}$ & Well-being is gender-neutral \\
\hline $\begin{array}{l}\text { 3. How has this representation of the } \\
\text { "problem» come about? }\end{array}$ & - \\
\hline $\begin{array}{l}\text { 4. What is left unproblematic in this } \\
\text { problem representation? }\end{array}$ & - \\
\hline $\begin{array}{l}\text { 5. Where are the silences? Can the } \\
\text { "problem» be thought about } \\
\text { differently? What effects are produced } \\
\text { by this representation of the } \\
\text { "problem»? }\end{array}$ & $\begin{array}{l}\text { The silences are that the roots of gender } \\
\text { inequality and gender discrimination } \\
\text { are not addressed in well-being } \\
\text { conceptualization. The "problem» can be } \\
\text { thought about differently when gender } \\
\text { analysis is included in gender-blind WBB } \\
\text { and gender mainstreaming is promoted. }\end{array}$ \\
\hline $\begin{array}{l}\text { 6. How/where has this representation } \\
\text { of the «problem» been produced, } \\
\text { disseminated and defended? How has } \\
\text { it been (or could it be) questioned, } \\
\text { disrupted and replaced? }\end{array}$ & Well-being gender budgeting \\
\hline
\end{tabular}

A central argument in this article is that overall, well-being budgeting approaches do not include gender analysis components such as addressing the root causes of gender-based discrimination, transforming imbalances in

Feminismo/s 35, junio 2020, pp. 29-61 
How to integrate a gender perspective into well-being budgeting practices:

Insights from a comparative case study between Bhutan and New Zealand

power relationships between men and women, recognizing and giving value to the care economy and the impacts of the different participation of men and women on unpaid work. The main reason why these components are not naturally included is because well-being is commonly conceptualized in a gender-neutral way as discussed in the following section on the cases of Bhutan and New Zealand.

Using WPR to analyse WBB, we observe that «the problem» is that the conceptualization of well-being and the way in which interventions are prioritized for planning and budgeting (e.g. policy priorities, well-being dimensions) are gender-blind as well as the tools used. Self-reporting well-being tools such as surveys are gender neutral (unless the gender perspective is included intentionally in the tool design) and collective and multidimensional well-being approaches tend to homogenize population needs and interest, which entails a «problem representation» (with the exception of WBGB). Some problem representations benefit the members of some groups at the expense of others (Bacchi, Analysing policy 44), with the effect that strategic needs and interest of some groups, especially women and girls, are hampered if this «problem» is not solved. The silences are that the roots of gender inequality and gender discrimination are not addressed in well-being conceptualization, and the concept of well-being is thought to be the same for men, women, girls and boys. The «problem» can be thought about differently when gender mainstreaming is fully integrated in WBB practices, starting with gender analysis of both revenue and expenditure decisions. For example, analyzing policy impacts on gender-based discrimination, imbalances in power relationships between men and women, the care economy and the impacts of the different participation of men and women on unpaid work. An illustrative example of this is the New Zealand GRB analysis of the 2016 Tax Expenditure Statement which indicated that the Tax Expenditure Statement in New Zealand lacked any gender specific analysis and that a number of the tax concessions have a potentially negative impact on gender equality (Morrissey, Gender Budgeting ii). Women earn less than men, have lower levels of savings and derive more of their income from wages than from wealth. This means that progressivity is particularly important for women (Morrissey, «Women and the Tax» 50). This representation of the problem is disrupted with the concept of «Well-being gender budgeting (WBGB)» which

Feminismo/s 35, junio 2020, pp. 29-61 
is a particular well-being budget approach that considers gender issues in its conceptualization and implementation.

Overall, the «problem» can be thought about differently by intentionally introducing a feminist conceptualization in WBB practices, along with all gender sensitive tools and competences for gender mainstreaming. In this way, both approaches - WBGB and gendered WBB - would be a specific type of GRB (See Figure 2).

Figure 2. Proposal for merging WBB with GRB
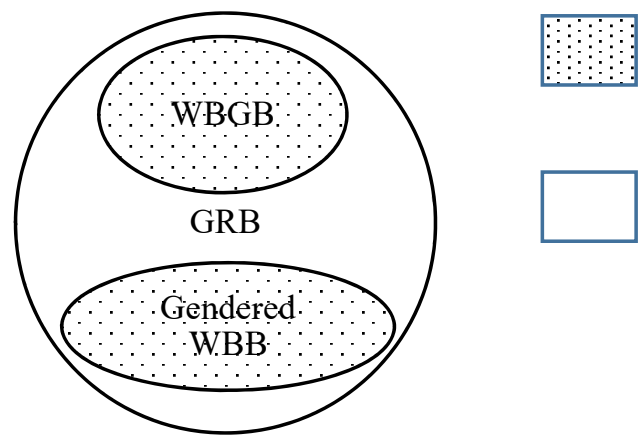

Well-being conceptualization: Capability Approach

Feminist conceptualization: Care economy, social reproduction work, addressing roots of gender discrimination

Source: Author's own elaboration

\section{BHUTAN AND NEW ZEALAND: A COMPARATIVE STUDY OF WELL-BEING BUDGETING}

\subsection{Comparing Well-being approaches, policy priorities and domains}

Currently in Bhutan, well-being is conceived under the Happiness Approach described in section 3, with four pillars that comprise Gross National Happiness (GNH) and nine domains that articulate the different elements of GNH. In New Zealand, the national budget is organized according to a set of well-being principles with five priority areas and twelve well-being domains. Both the policy pillars and the well-being domains are presented in Table 3. As this table shows, gender equality is currently neither a policy domain nor a policy priority in both countries. 
How to integrate a gender perspective into well-being budgeting practices:

Insights from a comparative case study between Bhutan and New Zealand

Table 3. Policy priorities and well-being domains and gender in Bhutan and New Zealand

\begin{tabular}{|c|c|c|c|c|c|}
\hline Country & & $\begin{array}{l}\text { licy pillars or } \\
\text { priorities }\end{array}$ & & Well-being domains & $\begin{array}{l}\text { Is gender } \\
\text { equality one } \\
\text { of the main } \\
\text { pillars? }\end{array}$ \\
\hline Bhutan & & $\begin{array}{l}\text { Good } \\
\text { governance, } \\
\text { Sustainable } \\
\text { socio- } \\
\text { economic } \\
\text { development, } \\
\text { Preservation } \\
\text { and promotion } \\
\text { of culture, and } \\
\text { Environmental } \\
\text { conservation. }\end{array}$ & $\begin{array}{l}\text { i) } \\
\text { ii) } \\
\text { iii) } \\
\text { iv) } \\
\text { v) } \\
\text { vi) } \\
\text { vii) } \\
\text { viii) } \\
\text { ix) }\end{array}$ & $\begin{array}{l}\text { Psychological well-being } \\
\text { Health } \\
\text { Time use } \\
\text { Education } \\
\text { Cultural diversity and } \\
\text { resilience } \\
\text { Community vitality } \\
\text { Good governance } \\
\text { Ecological diversity and } \\
\text { resilience } \\
\text { Living standards }\end{array}$ & No \\
\hline $\begin{array}{l}\text { New } \\
\text { Zealand }\end{array}$ & & $\begin{array}{l}\text { Taking } \\
\text { Mental Health } \\
\text { Seriously, } \\
\text { Improving } \\
\text { Child } \\
\text { Well-being, } \\
\text { Supporting } \\
\text { Māori and } \\
\text { Pasifika } \\
\text { Aspirations, } \\
\text { Building a } \\
\text { Productive } \\
\text { Nation, and } \\
\text { Transforming } \\
\text { the Economy. }\end{array}$ & $\begin{array}{l}\text { i) } \\
\text { ii) } \\
\text { iii) } \\
\text { iv) } \\
\text { v) } \\
\text { vi) } \\
\text { vii) } \\
\text { viii } \\
\text { ix) } \\
\text { x) } \\
\text { xi) } \\
\text { xii) }\end{array}$ & $\begin{array}{l}\text { Civic Engagement and } \\
\text { governance, } \\
\text { Cultural identity, } \\
\text { Environment, } \\
\text { Health, } \\
\text { Housing, } \\
\text { Income and consumption, } \\
\text { Jobs and earnings, } \\
\text { Knowledge and skills, } \\
\text { Time use, } \\
\text { Safety and security, } \\
\text { Social connection, and } \\
\text { Subjective well-being. }\end{array}$ & No \\
\hline
\end{tabular}

Source: Government of Bhutan, GNH Centre (Website, 18 February 2020) and Treasury in New Zealand (Website, 18 February 2020) 
The New Zealand Budget Policy Statement (BPS) is the first document in the budget cycle and sets out the five priorities for the Well-being Budget, which are the same for 2019 and 2020. In 2019, academics based in New Zealand conducted an initial gender impact analysis of the 2019 Well-being Budget which provided concrete examples on how gender analysis was missing in the policy priorities and well-being domains. For example, the policy priority «building a productive economy» did not consider the cost of inequality, such as violence against women and girls as something that negatively impacts on the country's economy. According to the assessment:

family violence costs New Zealand between $\$ 4.1$ to $\$ 7$ billion per year, with nearly $\$ 1$ billion a year in lost productivity in the workplace. Without intervention, the figure was predicted to result in a 10-year cumulative cost approaching $\$ 80$ billion (Curtin and Morrissey 1 ).

This led the researchers to conclude that «We cannot assume that a focus on well-being will automatically address gender inequalities» (Curtin and Morrissey 1).

\subsection{Comparing main tools used for well-being budgeting}

The main tools used in both countries for the Government to guide policymaking are presented in Table 4. None of these tools, except the New Zealand's tool «Bringing Gender In» integrate a gender analysis component in their design. However, most of them facilitate data for gender analysis as the table shows. 
How to integrate a gender perspective into well-being budgeting practices:

Insights from a comparative case study between Bhutan and New Zealand

Table 4. Main tools used in Bhutan and New Zealand for policymaking

\begin{tabular}{|c|c|c|c|}
\hline Country & Tools & $\begin{array}{l}\text { Are these tools } \\
\text { designed with a } \\
\text { gender approach? }\end{array}$ & $\begin{array}{c}\text { Do these tools } \\
\text { facilitate production } \\
\text { of data for gender } \\
\text { analysis? }\end{array}$ \\
\hline \multirow[b]{2}{*}{ Bhutan } & $\begin{array}{l}\text { 1) The GNH Screening } \\
\text { Tool }\end{array}$ & No & No \\
\hline & 2) GNH Happiness Index & No & $\begin{array}{l}\text { Yes. It provides sex- } \\
\text { disaggregated data } \\
\text { useful for gender } \\
\text { analysis of the } \\
\text { results }\end{array}$ \\
\hline \multirow{3}{*}{$\begin{array}{l}\text { New } \\
\text { Zealand }\end{array}$} & $\begin{array}{l}\text { 1) The Treasury's Living } \\
\text { Standards Framework }\end{array}$ & No & $\begin{array}{l}\text { Yes. It provides sex- } \\
\text { disaggregated data } \\
\text { useful for gender } \\
\text { analysis of the } \\
\text { results }\end{array}$ \\
\hline & 2) The LSF Dashboard & No & $\begin{array}{l}\text { Yes. It provides sex- } \\
\text { disaggregated data } \\
\text { useful for gender } \\
\text { analysis of the } \\
\text { results }\end{array}$ \\
\hline & 3) Bringing Gender In & Yes & Yes \\
\hline
\end{tabular}

Source: Author's own elaboration

In Bhutan, the main governmental tools are the GNH Screening Tool and the GNH Happiness Index. The objective of the GNH Screening tool is to systematically assess the impacts of any policy and project on GNH, thereby simultaneously selecting GNH enhancing policies and projects and rejecting projects and policies that adversely affect key determinants of GNH. The tool is applied to all policies and projects at the formulation stage of the policy process. However, this tool does not assess the gender impacts of the policies, either before (ex-ante) or after (ex-post) policy implementation. Therefore, it is missing an assessment of the potential consequences that each policy can have on gender equality. The methodology includes a set of «screening questions» that cover the nine domains of GNH in order to test their applicability in enhancing the values of GNH. To assess the result of the 
How to integrate a gender perspective into well-being budgeting practices:

Insights from a comparative case study between Bhutan and New Zealand

screening questions, there is a scoring system which, according to the GHN Centre website, is done by a heterogeneous group with diverse occupational backgrounds to work towards a consensus on project impacts. However, at the time of writing this article there was no reference to the ratio of women to men in this group, nor a reference to groups that could represent vulnerable segments of the population.

The GNH Happiness Index is based on a GNH Happiness Survey. It includes the nine domains, which are further supported by 33 indicators. The Index provides the framework for analyzing the happiness and well-being of the people. It also guides how policies may be designed to further create enabling conditions for the weaker scoring results of the survey. To conduct the analysis, it collects information disaggregated by sex and other categories such as region (rural, urban) and marital status. This allows an analysis of demographic groups. For instance, results of the 2010 Gross National Happiness showed that men were happier than women. Forty-nine per cent of men were happy, while only one-third of women were happy, a result considered statistically significant (Ura et al. 50). The data obtained in the survey allows sex differentiated results in each one of the nine domains, including relevant data for gender analysis such as time use. However, the questions in the survey to address the nine domains does not make reference to certain issues that affect women in particular. To illustrate this point, the domain «community vitality» used a set of questions to measure «family well-being», however:

1. In the questionnaire the definition of «family» is not clear. It seems to be the concept of «traditional family»; a heterosexual couple with descendants (children) and ascendants (third age) in the household. This excludes non-traditional families, for example, LGBTQ+. At the beginning of the questionnaire, there are no questions on sexual orientation or gender identity;

2. There are some references to time-use in relation to family (i.e. Do you get enough time to spend with your family?) but there is no mention of time spent on care or housework;

3. There is no variable to capture any possible violence within the family. There is, however, the variable «victim of crime» in the domain 
«safety in the community», which is where respondents are asked whether they have been a victim of a crime in the past 12 months. The crime indicator has a simple two-point scale of «yes» and «no» and does not allow for the identification of the type of crime, including inter-personal violence (IPV). There is, however, specific ethical guidance, such as the WHO and other specific questionnaires to collect data on gender based violence in a sensitive way, as there is often underreporting on IPV cases.

In New Zealand, the main tools used for the Government to guide policymaking are «The Treasury's Living Standards Framework» (LSF), a set of well-being indicators. These are related to the twelve domains to guide policy advice and the LSF Dashboard, a tool that supports the Treasury to use the LSF providing information on cross-government policy priorities. At the time of writing, the Policy Budget Statement 2020 and the LSF Dashboard, last updated in December 2019, highlighted that both tools are works in progress and that the Treasury will update the them in mid-2021 to better reflect priority areas. Data provided by both tools focuses on three sections: «Our country», «Our future», and «Our people». The Dashboard is linked to the LSF providing a set of indicators for each of these sections. It provides data disaggregated by sex and other information relevant for gender analysis. For example, in the section of «Our future», the indicator «Experience of discrimination» shows the percentage of people aged 15 years and older who reported having been subject to some form of discrimination in the previous 12 months. Examples of discriminatory treatment include racism, sexism and ageism. (Stats NZ Website, 18 February 2020). However, the information collected does not specify gender identity and sexual orientation and it only covers four types of ethnicities: Asian, European, Māori and Pacific, and four type of families: couple with or without children, not in a family nucleus and sole parent (McLeod 5). In addition, the LSF is missing time use data to conduct an analysis of its relation to unpaid work. Estimates of the impact of unpaid work on material standard of living are affected by a lack of regular time use data (Smith 47).

Ironically, the new Living Standards Framework does allow policymakers to value unpaid labour and address relevant inequities. [...]. In effect, then, the 
How to integrate a gender perspective into well-being budgeting practices:

Insights from a comparative case study between Bhutan and New Zealand

ability to measure whether unpaid and paid labour is equitably distributed, and the impact such distribution has on its sustainability for different genders, ethnicities and levels of abilities, is technically built in. Yet this potential is not being realised, given the inadequacy of the framework's measures related to unpaid work (Berentson-Shaw 49).

One of the challenges that has been discussed in New Zealand is related to «representation», which is aligned with the SDG concept of «leaving no one behind» and to one of the original aspirations of GRB to enhance democratic participation, civil society participation and accountability (Budlender and Hewitt 10). In the Third International Conference on Well-being and Public Policy held in Wellington in 2018, the concepts of diversity and inequality were highlighted, pointing out that it is not appropriate to assume sub-populations are homogeneous in their views on what contributes to well-being. This is regarded as a challenge in representation that aims that all voices are heard and that people feel that their well-being, what matters to them and their community is recognised (Weijers and Morrison 8).

As with the case in Bhutan, New Zealand tools are not designed from a gender approach. Women are slightly more likely than men to have low well-being across a number of domains, particularly Health, Housing and Social connections (McLeod 25). Larger differences are evident with respect to Safety and Income and consumption (McLeod 25). On the other hand, women reported higher levels of violence. According to the Ministry of Justice crime and victims survey, $4.8 \%$ of females over 15 years old reported that they were victims of family violence in 2018. This information is presented in the results of the well-being data, within the indicator of domestic violence. Despite all this evidence, there is not a specific focus on gender equality or women's empowerment indicators, however, several well-being indicators focus on children's well-being (e.g. «harm against children», «child poverty: material hardship», and «child poverty: low income») but without making the gender dimensions explicit. There is a general comment about these data gaps in the Dashboard update of 12 December 2019, which shows two weaknesses of the method; the first one is the failure in obtaining substantive information for evidence-based policy making, and the second one, the externalization of essential governmental tasks of policy making, to local governments and interest groups: 
How to integrate a gender perspective into well-being budgeting practices:

Insights from a comparative case study between Bhutan and New Zealand

The Dashboard does not provide the depth of quantitative and qualitative well-being evidence needed for agency policy analysis, such as the detailed distributional information needed for policy targeting. The Treasury expects agencies, local governments and relevant interest groups to develop their own well-being datasets, with a much deeper range of well-being data and evidence to analyse the performance of their sectors and policies (Treasury New Zealand, «The well-being budget 2019»6).

In addition, in New Zealand, there is another tool called «Bringing Gender In» available in the Ministry of Women in NZ's Website, for conducting gender assessments on the impact of policies. This gender-specific tool guides policymakers in the development a compulsory statement, which is required in papers for the Cabinet Social Well-being Committee on whether proposals have gender implications. It provides key questions, examples and links to useful data and other relevant material in order to develop a gender statement for the policy. The statement should say what has been done to consider the gender implications of a proposal. This tool draws on theoretical models and similar analysis tools, such as the Canadian tool «Gender-based Analysis Plus (GBA+)» introduced in New Zealand in 2019 and adapted to New Zealand's context. It is a policy-based tool which can be catalogued as an ex-ante GRB tool. This type of policy tools are basic in GRB implementation as

GRB must necessarily begin with purposive gender planning for each scheme/ sector, first by identifying the gender gaps in the sector and then delineating prioritized action points to address the gender gaps (Mishra and Sinha 56).

\subsection{Efforts made to introduce gender responsive budgeting}

In Bhutan, GRB has been attempted with some notable milestones in a gradual process that started with a «Gender Responsive Budgeting High Level Sensitization Workshop» in 2012. Since then, many GRB actions have been developed with the support of international cooperation, particularly by the United Nations. Examples include gender responsive policy and planning development, modification of budget documents to include a gender perspective, development of specific GRB tools and manuals as well as development of technical capacities, organization of working groups, gender focal points in all agencies and gender mainstreaming coordination bodies, improvements in the production and collection of gender-sensitive data and reports 
How to integrate a gender perspective into well-being budgeting practices:

Insights from a comparative case study between Bhutan and New Zealand

of gender analysis in specific sectors. The Ministry of Finance regards GRB as an important part of their Annual Report and presents the performance on gender equality measures and GRB to the Parliament. The most relevant milestones are found in two reports: a GRB report produced by UN Women in cooperation with the Royal Government of Bhutan in 2016 (Ganju and Jhamb), and the National Review Report on the Implementation of the Beijing Declaration and Platform for Action, June 2019.

In New Zealand, in 2016, there were limited signs of progress in introducing GRB. The OECD's 2016 gender budgeting survey showed that at that time the Government had not indicated any intention to adopt gender budgeting tools (Downes, Von Trapp, and Nicol 8). In 2018, a report produced by the Treasury pointed out that, «New Zealand could benefit from applying explicit gender budgeting as part of the pre-budget decision process or the post-budget reporting process» (Morrissey, «Gender Budgeting» ii). Since the well-being budget was approved in 2019 there have been some actions in favour of gender budget analysis, such as the introduction of the tool «Bringing Gender In» presented previously in section 4.2. As the tool has been introduced recently, it is too early to assess to what extent it could be successful to reach the aim of engendering WBB in New Zealand.

In sum, Bhutan has already begun to progressively introduce GRB complementary interventions. New Zealand, has introduced a GRB tool, «Bringing the gender in» that serves for the planning stage of public programmes. Both countries, are approaching GRB in different ways, with potential differences in future applications and outcomes.

\section{CONCLUSIONS AND RECOMMENDATIONS}

\subsection{Conclusions}

Gender blindness in well-being conceptualization: As this comparative case example showed, there is no unique formula or methodology for achieving well-being. Each country has a particular way of understanding and defining well-being and adapting their budget process to it, such as defining well-being dimensions, pillars, analytical categories and indicators to be considered in the planning and budgeting stages. Well-being budgeting, per se, does not entail an integrated approach to address gender inequality, nor to push for 
How to integrate a gender perspective into well-being budgeting practices:

Insights from a comparative case study between Bhutan and New Zealand

«gender transformative» measures that go beyond closing gender gaps. In reviewing the priority areas of Bhutan and New Zealand (Table 3), it becomes clear that gender inequality or any specific problems or demands related to it, such as addressing inter-personal violence or promoting the care economy, are not articulated as governmental priorities in both case studies. We can therefore say that the high-level policy priorities in both case studies are gender blind. This can be explained using the policy tool WPR proposed by Bacchi, which shows that the «representation of the problem» in both case studies were conceived with a «gender bias»: well-being is described and addressed in a gender-neutral way. Although in both case studies, it is possible to analyse data disaggregated by sex, such as the results in well-being by sex in each one of the well-being dimensions it doesn't mean that the focus of the planning and budgeting efforts are designed to solve inequality problems or to enhance gender equality outcomes.

GRB can improve well-being budgetary practices: Implementing commitments towards gender equality requires intentional measures to incorporate a gender perspective in planning and budgeting frameworks and concrete investment in addressing gender gaps (UN Women Website, 18 February 2020). GRB is a powerful approach to address gender inequality and to leave «no one behind» as the SDGs state. It favours data-driven policy decisions and the production of quantitative and qualitative data and information on the gender-differentiated impacts of policies and budget implementation.

Open window for engendering gender-neutral well-being budgetary practices:

With supportive political will, it is possible to introduce a gender perspective in well-being budgeting. Applying GRB in a comprehensive way should comprise the complete budget, both public revenues and expenditures as well as all stages of the budget cycle. There is a wide range of GRB tools and documented practices that can be adapted to specific contexts and budgetary practices, including well-being budgetary practices. The case study of Bhutan shows a continued effort to go in that direction. New Zealand has a specific gender analysis tool «Bringing Gender In», which can be a starting point to looking at policies and budgets with a gender lens. GRB entails not only the usage of analytical tools, it requires sustained interventions to transform planning and budgetary processes, likewise, it requires enhancement of individual and institutional capacities to achieve this purpose and maintain it over time.

Feminismo/s 35, junio 2020, pp. 29-61 
It is also important to recognise that the political will is essential at different levels of government. The Bhutan and New Zealand wellbeing budgeting and gender budgeting efforts are at national level, whereas the Wellbeing Gender Budgeting (WBGB) activities in Italy, Turkey and elsewhere have been a municipal government level. This important differential raises important question in relation to flexibility of government institutions at different levels of governance, proximity and permeability, openness to change and to engage with local initiatives. All of which indicate interesting pathways for future research building on this analysis of the distinctive methods and their combined potential, as set out in the following recommendations.

\subsection{RECOMMENDATIONS}

Responding to Bacchi's WPR question 5: Can the «problem» be thought about differently?, these are some initial measures that can serve to start building the basis for GRB work within gender-blind well-being budgeting experiences:

1. Political will to introduce GRB, despite the complexities that it can entail.

2. Collect and produce gender-sensitive data in a systematic way: e.g. sex-disaggregated data, time use surveys, violence against women surveys, among others.

3. Revise self-reporting well-being tools, and collective and multidimensional well-being approaches to ensure that the gender perspective is integrated.

4. Advocate for the introduction of gender equality objectives in the main well-being policy priorities.

5. Introduce and/or adapt GRB ex-ante tools to conduct gender assessments and gender responsive planning as well as ex-post tools for gender impact assessments and budget audits.

6. Ensure feminist perspectives are contained in any lists of capabilities, including on care work, unpaid work, removing roots of gender discrimination such as preventing gender-based violence.

7. Ensure capacity building efforts to strengthen the individual capacities of governmental staff with a role in planning and budgeting. 
How to integrate a gender perspective into well-being budgeting practices:

Insights from a comparative case study between Bhutan and New Zealand

8. Modify call circulars in order to make new procedures of gender responsive planning and budgeting compulsory and provide guidance on how to do it.

9. Establish a coordination body of key governmental and non-governmental actors working on GRB.

10. Explore possibilities to allow the participation of civil society organizations in GRB, such as production of non-governmental gender impact assessments, participation in GRB inter-multidisciplinary committees or participatory gender responsive budgeting practices (especially at local level), among others.

11. Document and share good practices and challenges.

\section{REFERENCES}

Addabbo, Tindara. «Gender budgeting in the capability approach. From theory to evidence». WiSE: Women in Scotland's Economy Series Conference 'Counting on Women-Gender, Care and Economics', Glasgow Caledonian University (2011). https://www.gcu.ac.uk/media/gcalwebv2/theuniversity/centresprojects/wise/ addabbo.pdf

Addabbo, Tindara, Diego Lanzi, and Antonella Picchio. «Gender auditing in a capability approach». CAPPaper 40. Centro di Analisi delle Politiche Pubbliche. Università di Modena e Reggio Emilia (2008): 1-44 https://core.ac.uk/download/pdf/6644003.pdf

Addabbo, Tindara, et al. «A social-reproduction and well-being approach to gender budgets: experiments at local government level in Italy». Gender and Well-Being. The Role of Institutions (2011): 105-124.

Addabbo, Tindara, et al. «Gender Budgeting From a Capability Approach Perspective: Evidences From Senegal». International Conference on Gender Research. Academic Conferences International Limited (2019): 15-23 https://search.proquest.com/openview/7188f110578b6ff23c02a011eb1c5a58/1?pq-origsite $=$ gscholar\&cbl=4451209

Addabbo, Tindara, Paula Rodríguez-Modroño, and Lina Gálvez-Muñoz. «Gender budgeting in education from a well-being approach: An application to Italy and Spain». Política económica 31.2 (2015): 195-212. 
How to integrate a gender perspective into well-being budgeting practices:

Insights from a comparative case study between Bhutan and New Zealand

Addis, Elisabetta, et al. "Gender and well-being: the role of institutions». In Gender and Well-Being: the role of institutions. Abingdon, Oxon: Routledge, 2016. 21-46.

Alkire, Sabina. «The capability approach and well-being measurement for public policy». OPHI Working Paper 94 (2015): 1-34.

Anwar, Samina, Anna Downs, and Euan Davidson. How Can PFM Reforms Contribute to Gender Equality Outcomes? New York: UN Women \& DFID, 2016. https://gender-financing.unwomen.org/es/resources/h/o/w/ how-can-pfm-reforms-contribute-to-gender-equality-outcomes

Bacchi, Carol Lee. Analysing policy: What's the problem represented to be?. Frenchs Forest, N.S.W: Pearson Australia, 2009.

Bacchi, Carol Lee. «Introducing the 'What's the problem represented to be?'approach». Engaging with Carol Bacchi: Strategic Interventions and Exchanges. Ed. Angelique Bletsas and Chris Beasley. South Australia: University of Adelaide Press, 2012. 21-24.

Berentson-Shaw, Jess. «Where There is a Will: Encouraging policymakers to value unpaid labour». Policy Quarterly Volume 15, Issue 1 (2019): 46-53. Doi: https://doi.org/10.26686/pq.v15i1.5296

Binder, Martin. «Subjective Well-being Capabilities: Bridging the Gap Between the Capability Approach and Subjective Well-being Research». Journal of Happiness Studies 15.5 (2014): 1197-1217. Doi https://doi.org/10.1007/ s10902-013-9471-6

Biswas-Diener, Robert, Ed Diener, and Nadezhda Lyubchik. «Well-being in Bhutan». International Journal of Well-being 5.2 (2015): 1-13. Doi:10.5502/ ijw.v5i2.1

Budlender, Debbie, and Guy Hewitt. Gender Budgets Make More Cents: Country Studies and Good Practice. London, UK: Commonwealth Secretariat, 2002. https://www.femtech.at/sites/default/files/How_to_do_a_gender-sensitive_ budget_analysis.pdf

Budlender, Debbie, Rhonda Sharp, and Kerri Allen. How to do a gender-sensitive budget analysis: Contemporary research and practice. London, UK: Commonwealth Secretariat, 1998. https://www.femtech.at/sites/default/files/ How_to_do_a_gender-sensitive_budget_analysis.pdf

Cavaghan, Rosalind. «Gender knowledge: A review of theory and practice». Gender Knowledge and Knowledge Networks in International Political Economy. 
How to integrate a gender perspective into well-being budgeting practices:

Insights from a comparative case study between Bhutan and New Zealand

Volume 3. Ed. by Brigitte Young and Christoph Scherrer. Munich: Nomos Verlagsgesellschaft (2010):18-36. Doi: 10.5771/9783845223858-18

Coscieme, Luca, et al. «Overcoming the Myths of Mainstream Economics to Enable a New Well-being Economy». Sustainability 11.16 (2019): 2-17. Doi: 10.3390/sul1164374

Council of Europe. Steering Committee for Equality between Women, and Men. Group of Specialists on Mainstreaming. Gender mainstreaming: Conceptual framework, methodology and presentation of good practices. Strasbourg: Council of Europe, 2004.

Curtin, Jennifer, and Morrisey, Suzy. »Where does gender equality fit into the Budget?». Ideasroom. 31 May 2019: 1 https://www.newsroom. co.nz/ideasroom/2019/05/31/614191/where-does-gender-equality-fitinto-the-budget

Downes, Ronnie, Lisa Von Trapp, and Scherie Nicol. «Gender budgeting in OECD countries». OECD Journal on Budgeting 16.3 (2017): 71-107.

Galizzi, Giovanna, Gaia Viviana Bassani, and Cristiana Cattaneo. «Adoption of Gender-Responsive Budgeting (GRB) by an Italian Municipality». Administrative Sciences 8.4 (2018): 68.

Ganju Thakur, Sarojini, and Bhumika Jhamb. Gender Responsive Planning and Budgeting in Bhutan: From Analysis to Action. UN Women in collaboration with the Royal Government of Bhutan and suppot of Asian Devekopment Bank, 2016. https://asiapacific.unwomen.org/en/digital-library/ publications/2016/05/gender-responsive-planning-and-budgeting-in-bhutan Government of Bhutan, GNH Centre. Website. http://www.gnhcentrebhutan.org/ Gunluk-Senesen, Gulay, et al. «Gender Budgeting in Turkey: An Assessment of Local Practices from the Well-Being Perspective». Politica Economica/ Journal of Economic Policy 31.2 (2015): 175-194.

Hough-Stewart, Lisa, et al. What is a wellbeing economy? Different ways to understand the vision of an economy that serves people and planet. WEALL. Wellbeing Economy Alliance, December 2019. https://wellbeingeconomy.org/wp-content/uploads/2019/12/A-WE-Is-WEAll-Ideas-Little-Summaries-of-Big-Issues4-Dec-2019.pdf

Khan, Zohra. «Gender-Responsive Budgeting». Encyclopedia of Business and Professional Ethics. Ed. Deborah C Poff, Alex C. Michalos. Springer Nature Switzerland AG. 2019. https://doi.org/10.1007/978-3-319-23514-1_141-1 
How to integrate a gender perspective into well-being budgeting practices:

Insights from a comparative case study between Bhutan and New Zealand

Klatzer, Elisabeth, and Barbara Stiegler. «Gender budgeting-an equality policy strategy». Friedrich-Ebert-Stiftung and Shanghai Coordination Office for International Cooperation. Briefing Paper Shanghai. N. ${ }^{\circ} 12$. (2011): 1-8. https://ibrary.fes.de/pdf-files/bueros/china/11416.pdf

Klatzer, Elisabeth, et al. «Developments in Practice: Methodologies and Approaches to Gender Budgeting». Gender Budgeting in Europe. Ed. Angela O'Hagan and Elisabeth Klatzer. Palgrave Macmillan, Cham, 2018. 109-133. Doi: 10.1007/978-3-319-64891-0_6

McLeod, Keith. Our People-Multidimensional wellbeing in New Zealand (Analytical Paper 18/04). 4 December 2018. The Treasury of New Zealand. https://treasury.govt.nz/publications/ap/ap-18-04

Middlemiss, Lucie. «Commentary on 'Sustainability and Well-Being: A Happy Synergy'». Great Transition Initiative, April 2017.

Ministry for Women in New Zealand. Website. https://women.govt.nz/gender-tool Mishra, Yamini, and Navanita Sinha. "Gender Responsive Budgeting in India: What Has Gone Wrong?». Economic and Political Weekly Vol. 47, No. 17 (2012): 50-57. https://www.jstor.org/stable/23214838

Morrissey, Suzy. Gender Budgeting: A Useful Approach for Aotearoa New Zealand. (WP 18/02) 18 April 2018. The Treasury of New Zealand. https://treasury. govt.nz/publications/wp/wp-18-02

Morrissey, Suzy. «Women and the Tax Working Group». Journal of Australian Taxation Vol 21 (2). New Zealand Specials Edition. (2019): 50-64 https://www. jausttax.com.au/Articles_Free/JAT\%20Volume\%2021\%20Issue\%202\%20 -\%20NZ\%20Special\%20Edition.pdf

Nussbaum, Martha C. «Human capabilities, female human beings». Women, Culture and Development: A Study of Human Capabilities. Ed. Martha C. Nussbaum and Jonathan Glover. A study prepared for World Institute Economics Research (WIDER) of the United Nations University. Oxford: Clarendon Press, 1995.

Nussbaum, Martha C. Women and Human Development: The Capabilities Approach. Vol. 3. Cambridge: United Kingdom. The Press Syndicate of the University of Cambridge, 2000.

O'Hagan, Angela. «Favourable conditions for the adoption and implementation of gender budgeting: Insights from comparative analysis». Politica economica, Journal of Economic Policy. 31.2 (2015): 233-252. Doi: 10.1429/80935 
How to integrate a gender perspective into well-being budgeting practices:

Insights from a comparative case study between Bhutan and New Zealand

Picchio, Antonella, ed. Unpaid work and the economy: a gender analysis of the standards of living. London and New York: Routledge, 2003.

Robeyns, Ingrid. «Sen's capability approach and gender inequality: selecting relevant capabilities». Feminist Economics. 9:2-3 (2003): 61-92. https://doi. org/10.1080/1354570022000078024

Robeyns, Ingrid. «The Capability Approach: a theoretical survey». Journal of Human Development 6:1 (2005): 93-117. Doi: 10.1080/146498805200034266

Robeyns, Ingrid. Wellbeing, Freedom and Social Justice: The Capability Approach Re-Examined. Cambridge, England: Open Book Publishers. 2017. Doi:10.11647/OBP.0130

Royal Government of Bhutan. The National Commission for Women and Children. National Review Report on the Implementation of Beijing Declaration and Platform for Action. June 2019. http://www.asiapacificgender.org/sites/default/ files/documents/Bhutan\%20(English).pdf

Sen, Amartya Kumar. «The standard of living: lecture II, lives and capabilities». The standard of living. Ed. Geoffrey Hawthorn. Cambridge: Cambridge University Press, 1987. 20-38. https://doi.org/10.1017/CBO9780511570742.003

Sen, Amartya Kumar. Inequality Reexamined. New York Russell Sage Foundation Cambridge, MA, Harvard University Press, 1992.

Sen, Amaryta Kumar. «Capability and Well-being». The quality of life. Eds. Martha Nussbaum and Amaryta Sen. Oxford Scholarship Online, November 1993. https://doi.org/10.1093/0198287976.003.0003

Sen, Amartya Kumar. The idea of justice. Cambridge: The Belknap Press of Harvard University Press, 2009.

Sharp, Rhonda, and Diane Elson. Improving budgets: A framework for assessing gender responsive budget initiatives, accessed on 15 May 2020. https://www. unisa.edu.au/siteassets/episerver-6-files/documents/eass/hri/gender-budgets/ sharp-elson-improving-budgets.pdf

Smith, Conal. «Treasury Living Standards Dashboard: Monitoring Intergenerational Well-being». Commissioned report. 7 Juny 2018. The Treasury of New Zealand. https://treasury.govt.nz/publications/commissioned-report/ treasury-living-standards-dashboard-monitoring-intergenerational-wellbeing Stats NZ. Well-being statistics. Website. https://www.stats.govt.nz/topics/well-being Stewart, Frances. "Against happiness: A critical appraisal of the use of measures of happiness for evaluating progress in development». Journal of Human Development and Capabilities 15.4 (2014): 293-307. 
How to integrate a gender perspective into well-being budgeting practices:

Insights from a comparative case study between Bhutan and New Zealand

Stotsky, Janet Gale. Gender budgeting: Fiscal context and current outcomes. WP/16/149. Washington, District of Columbia: International Monetary Fund, 2016. http://dx.doi.org/10.5089/9781475575460.001

Treasury, New Zealand. The well-being budget 2019. Website: https://treasury.govt. nz/publications/wellbeing-budget/wellbeing-budget-2019-html

Treasury, New Zealand. The Living Standards Framework: Dashboard Update. Treasury Paper. December 2019. https://treasury.govt.nz/publications/tp/ living-standards-framework-dashboard-update

Treasury, New Zealand. The well-being budget 2020. Website: https://budget.govt. nz/budget/2020/wellbeing/approach/index.htm

Treasury, New Zealand. Website. https://treasury.govt.nz/

Trebeck, Katherine. Supporting but not synonymous: the wellbeing economy and a gender-equal economy. Paper commissioned by The Women's Budget Group. 6 April 2020.

United Nations. The Sustainable Development Goals Report 2019. New York: United Nations, 2019. https://unstats.un.org/sdgs/report/2019/

United Nations Committee for Development Policy (UNCDP). Leaving no one behind. New York: United Nations, 2018. https://www.un.org/development/ desa/dpad/wp-content/uploads/sites/45/CDP-excerpt-2018-1.pdf

UN Women. Financing For Gender Equality. Website. 18 February 2020. https:// gender-financing.unwomen.org/es

Ura, Karma, et al. An Extensive Analysis of Gross National Happiness Index. Thimphu, Bhutan: The Centre for Bhutan Studies, 2012.

Villagómez, Elisabeth, et al. Gender budgeting. Mainstreaming gender into the EU budget and macroeconomic policy framework. European Institute for Gender Equality (EIGE). Luxembourg: Publications Office of the European Union, 2018.

Villalba, Unai, Yolanda Jubeto, and Luis Guridi. «Participation and gender in Latin America: perspectives from decentralized cooperation and Local Human Development approaches». Community Development Journal 49.2 (2014): 228-244.

Weijers, Dan, and Phillip S. Morrison. «Well-being and Public Policy: Can New Zealand de a leading light for the 'wellbeing approach'?». Reflections on the Third International Conference on Wellbeing and Public Policy, Beehive and Victoria University of Wellington, 5-7 September 2018». Policy Quarterly 
How to integrate a gender perspective into well-being budgeting practices:

Insights from a comparative case study between Bhutan and New Zealand

Volume 14 Issue 4. November 2018. https://www.victoria.ac.nz/_data/assets/ pdf_file/0008/1713626/Weijers_Morrison.pdf

Wellbeing Economy Alliance. Website. https://well-beingeconomy.org/

Yucel, Yelda, and Gulay Gunluk -Senesen. «Sustainability of Gender Budgeting in Local Administrations in Turkey: An Assessment from the WellBeing Perspective». Gender Budgeting in Europe. Ed. Angela O'Hagan and Elisabeth Klatzer. Palgrave Macmillan, Cham, 2018. 271-293. Doi: 10.1007/978-3-319-64891-0_6 